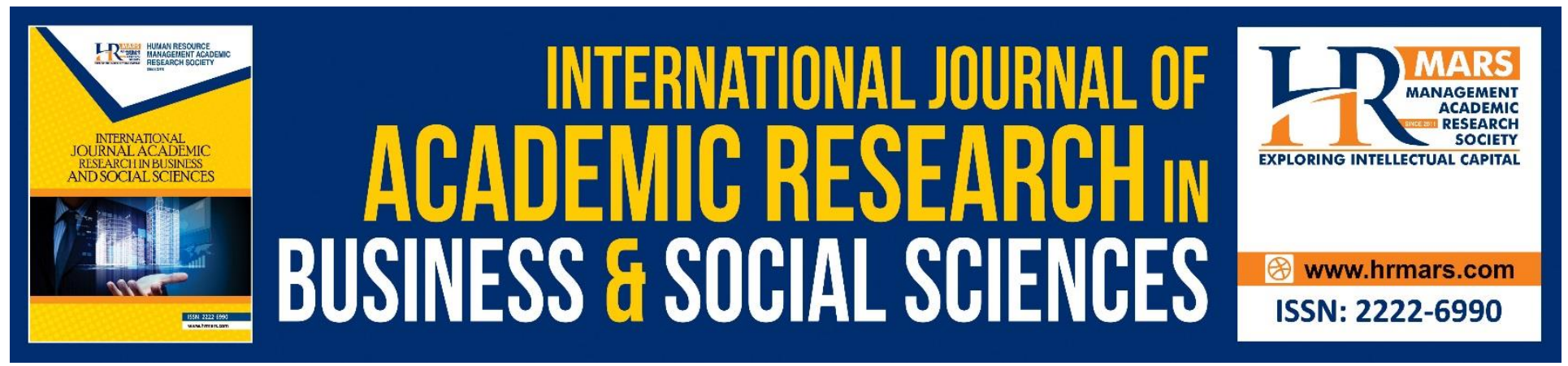

\title{
Attribute Assessment Instrument on Information Management and Lifelong Learning Skills among UPSI Students in Faculty of Sports Science and Coaching
}

Ahmad Hashim, Thariq Khan Azizuddin Khan, Zulakbal Abd Karim \& Norhazira Abdul Rahim

To Link this Article: http://dx.doi.org/10.6007/IJARBSS/v9-i2/5596

DOI: $\quad 10.6007 /$ IJARBSS/v9-i2/5596

Received: 29 Jan 2019, Revised: 21 Feb 2019, Accepted: 06 March 2019

Published Online: 14 March 2019

In-Text Citation: (Hashim, Khan, Karim, \& Rahim, 2019)

To Cite this Article: Hashim, A., Khan, T. K. A., Karim, Z. A., \& Rahim, N. A. (2019). Attribute Assessment Instrument on Information Management and Lifelong Learning Skills among UPSI Students in Faculty of Sports Science and Coaching. International Journal of Academic Research in Business and Social Sciences, 9(2), 632-642.

\section{Copyright: (c) 2019 The Author(s)}

Published by Human Resource Management Academic Research Society (www.hrmars.com)

This article is published under the Creative Commons Attribution (CC BY 4.0) license. Anyone may reproduce, distribute, translate and create derivative works of this article (for both commercial and non-commercial purposes), subject to full attribution to the original publication and authors. The full terms of this license may be seen at: http://creativecommons.org/licences/by/4.0/legalcode

Vol. 9, No. 2, 2019, Pg. 632 - 642

http://hrmars.com/index.php/pages/detail/IJARBSS

JOURNAL HOMEPAGE

Full Terms \& Conditions of access and use can be found at http://hrmars.com/index.php/pages/detail/publication-ethics 


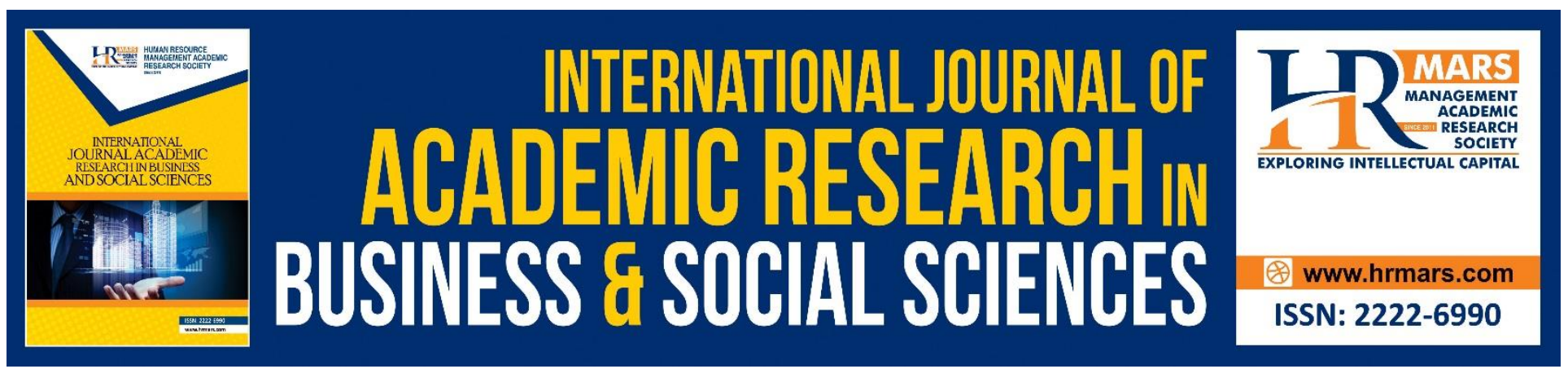

\title{
Attribute Assessment Instrument on Information Management and Lifelong Learning Skills among UPSI Students in Faculty of Sports Science and Coaching
}

\author{
Ahmad Hashim, Thariq Khan Azizuddin Khan, Zulakbal Abd Karim \& \\ Norhazira Abdul Rahim \\ Faculty of Sports Science and Coaching, Universiti Pendidikan Sultan Idris, Tanjong Malim, Perak \\ Email: ahmad@fsskj.upsi.edu.my
}

\begin{abstract}
This study attempts to design a questionnaire for attribute assessment instrument on information management and lifelong learning skills among students at the Faculty of Sports Science and Coaching, Sultan Idris Education University (UPSI). Three variables are used to measure the attributes of information management and lifelong learning skills, among which are finding and managing various forms of information, autonomous learning and curious minds. A total of 212 Sports Science students were selected as the study sample. The study analysis uses Cronbach's alpha to obtain reliability of the instrument. Factor analysis is used to obtain validity of the attribute assessment instrument on information management and lifelong learning skills. Based on factor analysis, the findings showed that 54 questionnaire items are valid from the overall 60 items constructed. All questionnaire items obtained high reliability value which is $r=.93$.
\end{abstract}

Keywords: Information Management, Lifelong Learning, Managing Various Information, Autonomous Learning and Curious Mind.

\section{INTRODUCTION}

Higher education system as outlined by the Ministry of Higher Education has its own vision and mission on successful outcome and good interest of every students. The Ministry of Higher Education has also emphasized on the importance of giving equal priority on both knowledge and morality. The Malaysia Education Blueprint 2015-2025 (Ministry of Higher Education, 2015) is intended to meet student aspirations that include ethics and spirituality, leadership skills, national identity, language skills, thinking skills and knowledge. We are now in the era of facing the 4.0 education revolution 
which is increasingly challenging to all parties. The latest development in industrial technology such as artificial intelligence, intelligence machines, cloud technology and robotics will certainly give a big challenge to all graduates. In this regard, UPSI students at the Faculty of Sports Science and Coaching (FSSK) need to be educated and guided in preparation for a challenging future. They should be wellequipped with solid knowledge and empowered with balanced ethical and spiritual values. The Ministry of Higher Education (2016) has presented the guideline, that each graduate must master and possess the features outlined in the Learning Outreach Domain (DHP), from the Malaysian Qualifications Framework, among which are mastery of knowledge, competency in practical or physical skills as well as capability in social skills and responsibilities. The Malaysia Education Blueprint 2015-2025 (MHE 2015) is designed based on the vision and aspirations in educating talented, skilled and knowledgeable students who are fully prepared to face the challenges of the 21st century. The Development Plan aims to develop a holistic, balanced and entrepreneurial graduates in line with the National Education Philosophy. One of the MHE initiatives is the implementation of an integrated assessment system that reveals the holistic achievement of students as a result of learning experience. Integrated Cumulative Grade Value Assessment (Integrated CGPA) aims to drive constructive alignment practices to ensure the curriculum design, curriculum implementation and assessment process at the course and program level are of high quality. Integrated CGPA is a system or mechanism for evaluating and reporting on integrated student enhancement and development in the aspect of manners (ethics and noble values), declarative and functional knowledge and their technical skills in discipline. This mechanism aims to help stakeholders plan and determine the most aligned steps of improvement. Integrated CGPA Reporting also demonstrate a holistic achievement of students as well as their achievements for each program's learning outcomes throughout the course of study.

To ensure the success of Integrated CGPA reporting, an instrument for attribute assessment on Learning Outcome Domain (LOD) from the Malaysian Qualification Framework (MQF) should be developed and validated to assess students' performance that are holistic, entrepreneurial and balanced. This study aims at developing and determining the attribute assessment instrument validity for LOD of MQF targeted at UPSI students from the Faculty of Sports Science and Coaching. The construct of this assessment instrument is based on Social Skill and Responsibility attributes. There are three important goals in Malaysian Higher Education. Firstly is to give priority to human capital development in providing skilled manpower and capable of facing future challenges. Secondly, to fulfill the aspirations of students in ethical and spiritual aspects, leadership skills, national identity, language skills, thinking skills and knowledge. Hamat and Nordin (2012) have emphasized that human capital development is an effort towards creating knowledgeable, skilled, innovative, selfemployed, ethical, educated, well-trained and employed, possessed high moral values, wellmannered, courteous, disciplined, dynamic, innovative, creative, patriotic, fair, progressive, determined and competitive.

The human capital development has its own educational goals to enhance personality and holistically develop students' ability through the learning of specialized skills, realizing their intellectual, physical and spiritual capabilities and generating excellent human capital. To achieve remarkable quality of human capital development, this endeavour requires a holistic approach and emphasizes on the development of knowledge, thinking skills, leadership skills, bilingual skills, 
spiritual ethics and national identity. The UPSI Sports Science Curriculum, as offered at the Faculty of Sports Science and Coaching namely Physical Education, Coaching Science, Rehabilitation Science and Sports Psychology will produce students with excellent human capital characteristics. The curriculum and co-curricular activities designed will also create a more cheerful and enjoyable learning climate and culture thus bringing positive impact to the students (Nurul Haerani Mohamad \& Ahmad Esa (2013). Active student participation in curriculum and co-curricular activities such as uniformed bodies, associations, clubs and sports are important for them to build their personality and leadership qualities. The holistic student development requires involvement in both academic and co-curricular areas. Students will learn and embrace leadership qualities, ethics and spirituality, leading skills, national identity, language skills, thinking skills and knowledge. Good education will ensure that graduates continue to be relevant to the current market requirements. Moreover, graduates will be more prepared to gear themselves up for a more challenging and competitive environment, realizing that present global economic climate is now in the era of knowledge-based economy that mostly focus on science and technology. Considering impression by future employers and increasing job demands, graduates need to possess not only academic qualifications but also capabilities and skills as an added value to engage employers' attention (Rinaldi, Hamzah \& Nordin, 2015). Mohamad and Esa (2013) in their study argued that human capital development is not limited only to academic discipline and skill enhancement alone, but also includes development of mind, spiritual, personality and ethics. Human capital with these features ensure that transformation and development of individuals, families, communities, nations and the world would take place in a more structured manner. According to Jalil (2014), well-organized human capital development will create a knowledgeable and highly skilled workforce. The development of human capital however is not limited to the discipline and skills enhancement alone. It also includes growth of mind, spiritual, personality and ethics.

The development of human capital in education will also focus on personality enhancement of graduates to produce a balanced human capital in terms of skills, patriotism, discipline and pure value towards the creation of a human capital of a nation with towering personality. Human capital assessment carried out in the faculty curriculum will further boost the national education system. Ahmad (2015) in his research stated that testing, measurement and evaluation are important components in the learning and teaching process. Results from study measurements and assessments can provide educators with information on the effectiveness of the approach, strategy or technique used. The construct of this questionnaire measurement instrument is based on selfassessment method. It can be defined as graduates evaluating their own work based on the criteria outlined (Prihamdani, 2016). The construction of this instrument questionnaire is a way for students to make self-evaluation on their level of information management and lifelong learning skills based on the criteria discussed earlier. Maskan (2013) in his work addressed that self-assessment in curriculum activities is an important tool to improve academic performance and ability. Learning will improve with self-assessment because it meets the learning objectives to be measured (Daniel, 2010, Ghani \& Crow, 2017). The importance of self-assessment allows students to understand their learning goals and find out what they need to achieve (Mohd Faizal Nizam Lee Abdullah \& Leow Tze Wei, 2017). 


\section{Objective}

This study aims to design an instrument of questionnaire items. It also determines reliability and validity of attribute assessment instrument on information management and lifelong learning skills among students of Science Sports Program, Faculty of Sports Science in UPSI.

\section{METHODOLOGY}

Methodology of this study focuses on the study design, study population and sample, conceptual framework, research instrumentation, pilot study, data collection procedures, and data analysis procedures.

\section{Research Design}

This study is a quasi-experimental design using one group post-test only method (Ary, Jacobs \& Razavieh, 2002). The study is divided into three stages. The first stage of this study aims to create an assessment instrument questionnaire and to obtain validity of field experts. The second stage seeks to obtain reliability of assessment instrument on information management and lifelong learning skills. While the third stage attempts to obtain validity of the items to ensure that each item represents the component of information management and lifelong learning skills.

\section{Sample}

All male and female students from first semester to eighth semester in Semester 1, Session 20182019 who are currently attending all courses offered at the Faculty of Sports Science and Coaching in UPSI are considered population of this study. Sample size selection for this study is based on Power Tables for Effect Size from Cohen (1992), with the sampling power value of .80, the effect of size (d) .30 , the power of .80 and the significant level at $\alpha=.05$. Based on the formula, the sample size should be 175 people. However, the researchers used a sample size of 212 (125 = men, $75=$ female) after considering the absence or mortality factor (Tuckman \& Waheed, 1981) that could possibly happen. All study samples were randomly selected.

\section{Variables}

In this study the dependent variable is the attribute score of information management and lifelong learning skills. The variable is measured based on three sub attributes namely finding and managing various forms of information, autonomous learning and curious minds. While independent variables are gender and type of programs followed by UPSI students at the Faculty of Sports Science and Coaching. Figure 3.1 shows the study variables.

\section{Instrument}

The researchers have adapted and modified the assessment instrument in the form of scale review (ICGPA, MHE 2015) to five scaled questionnaires ( 1 = very weak, 2 = weak, 3 = satisfactory, $4=$ good and $5=$ very good). A total of 60 questionnaire items were constructed at the early stage of this study to evaluate the three sub attributes namely finding and managing various forms of information, autonomous learning and curious minds. A number of 212 subjects were used in the actual study to test validity and reliability of the instrument items. 


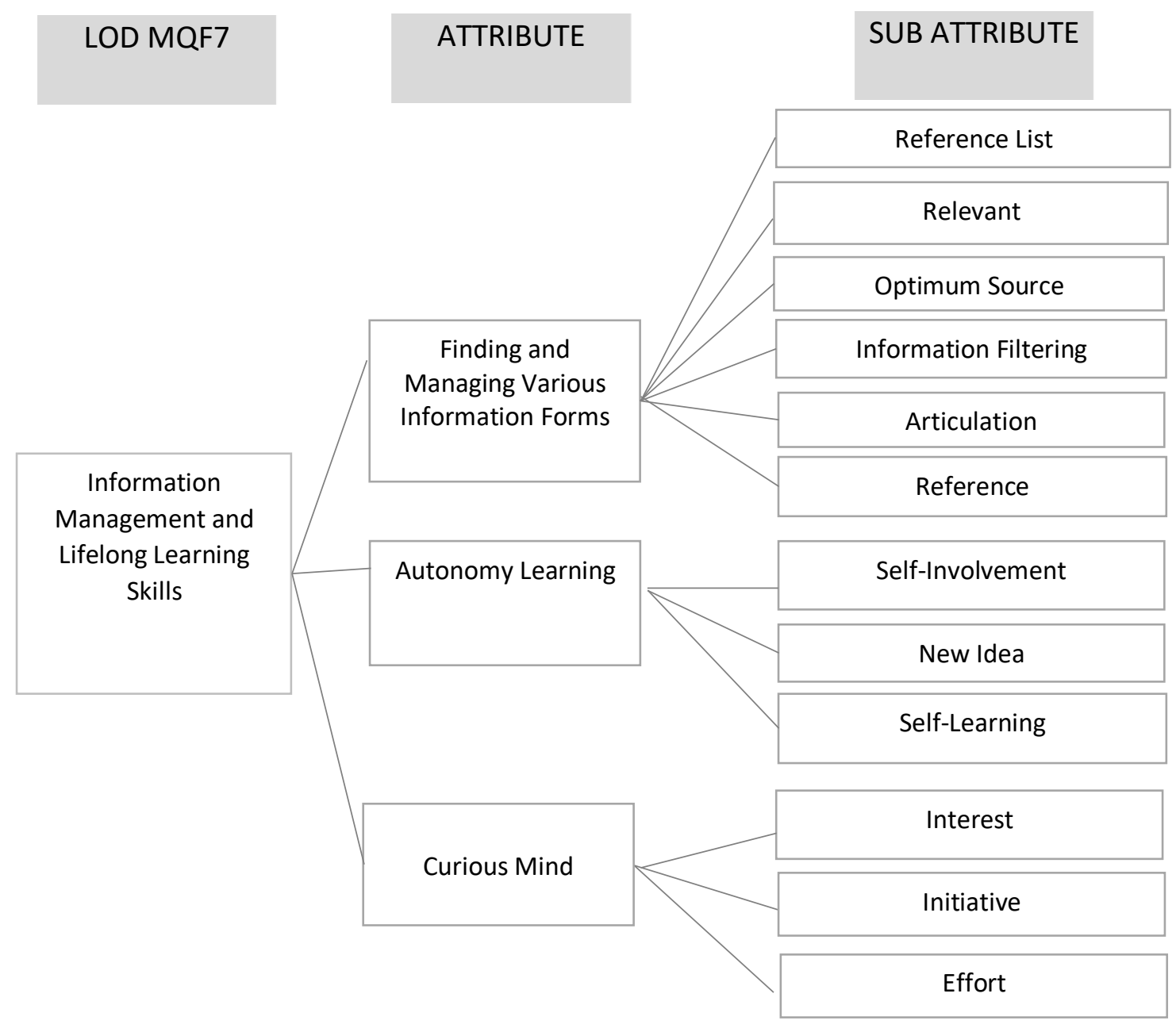

Figure 3.1: Variables of Study

\section{Data Analysis Procedures}

Data obtained from the questionnaires will be analyzed using the SPSS 20.0 (Statistical Package for Social Science 20.0) software. Data analysis from the first part of this study was carried out using the Pearson Product Moment correlation statistic method to obtain validity of field experts based on agreement of two expert panels. The researchers used the Cronbach's alpha analysis to obtain the reliability and consistency of questionnaire instrument items. The factor analysis method is used to obtain validity of isolated construct, and to ensure that each item is placed in the proper component (Ahmad, 2014). 
INTERNATIONAL JOURNAL OF ACADEMIC RESEARCH IN BUSINESS AND SOCIAL SCIENCES

Vol. 9, No. 2, Feb, 2019, E-ISSN: 2222-6990 C 2019 HRMARS

\section{RESULTS}

With reference to a study by Sidek Mohd Noah \& Jamaludin Ahmad (2005), for expert panel evaluation on 10 questionnaires being valued at scale 1 to 5 to verify the instrument of questionnaire, the value of validity obtained will be $r=.91$. A total of 65 questionnaires have been developed to assess the performance of attributes namely information management and lifelong learning skills based on three sub components. The sub components are finding and managing various information forms, autonomous learning skills and curious minds. Following the analysis, only 54 items are valid. Cronbach's alpha analysis shows that the reliability value on information management and lifelong learning skills is $r=.93$. Table 1,2 and 3 show the results of factor analysis.

Table 1. Barlett's and Kaiser-Meyer-Olkin test results

\begin{tabular}{lll}
\hline $\begin{array}{l}\text { Kaiser-Meyer-Olkin Measure of } \\
\text { Sampling Adequency }\end{array}$ & .861 \\
\hline Barlett's Test of Sphericity & Approx. Chi Square & 9909.477 \\
& Df & 1770 \\
& Sig. & .000 \\
\hline
\end{tabular}

Kaiser's criterion technique was used to determine the number of components. Components with only one or more eigenvalue were selected in this analysis. There are four analysis components with more than one eigenvalue. Finding in Table 1 shows the results of all the 60 attribute analysis components on information management and lifelong learning skills explained 86.00 per cent variance. The matrix component shows loading in each line expressed that each survey item's correlation with sub attributes comprising finding and managing various information forms, autonomous learning skills and curious minds.

Table 2. Total Variance Explained

\begin{tabular}{cccc}
\hline \multirow{2}{*}{ Component } & \multicolumn{3}{c}{ Rotation Sums of Squared Loadings } \\
& Total & 16.464 & Cumulative \% \\
\hline 1 & 9.878 & 16.204 & 16.464 \\
2 & 9.722 & 16.201 & 32.668 \\
3 & 9.721 & 48.869 \\
\hline
\end{tabular}

Extraction Method: Principal Component Analysis

To maintain all the four components for next analysis, the researchers used varimax rotation method to minimize number of survey items which had high correlation on each factor. According to Tabachnick and Fidell (2007) results based on orthogonal rotation was easier to be translated and reported. Table 2 shows the results of three components rotation using the varimax rotation method. The findings show that the first component explained 16.46 per cent of variance, the second component explained 16.20 per cent of variance and third component explained 16.20 per cent variance. Total amount of variant available which could be explained by all three components was 48.87 per cent variance and the figure remained after rotation. 
INTERNATIONAL JOURNAL OF ACADEMIC RESEARCH IN BUSINESS AND SOCIAL SCIENCES Vol. 9, No. 2, Feb, 2019, E-ISSN: $2222-6990$ ๑ 2019 HRMARS

Table 3 shows the loading for each attribute survey item on information management and lifelong learning skills. Based on Principal Component Analysis, from the overall 60 survey items created only 54 items showed high communality score. Component line one, represented assessment instrument of sub attributes on searching and manage various forms of information, the second line represented learning autonomy skills and the third line represented curious mind. Selection of construct component for all sub attributes in this study was based on high main loading and it exceeded the correlation coefficient value $r=0.50$. This is because high correlation value of a test on a measured factor indicated close relation with the factor. According to Pallant (2005), based on this significant finding, 54 items in this analysis are considered valid for attribute assessment instrument on information management and lifelong learning skills in this research.

Table 3 Construct Validity for Rotated Component Matrix Component

\begin{tabular}{|c|c|c|c|}
\hline \multicolumn{4}{|c|}{ Component } \\
\hline & 1 & 2 & 3 \\
\hline s15e & .752 & & \\
\hline s40e & .733 & & \\
\hline s20e & .730 & & \\
\hline s60e & .728 & & \\
\hline$s 5 e$ & .696 & & \\
\hline s30e & .667 & & \\
\hline s45e & .660 & & \\
\hline s10e & .653 & & \\
\hline s55e & .647 & & \\
\hline s29e & .643 & & \\
\hline s25e & .638 & & \\
\hline s59e & .622 & & \\
\hline s39e & .619 & & \\
\hline s34e & .609 & & \\
\hline s4e & .604 & & \\
\hline s50e & .563 & & \\
\hline s35e & .560 & & \\
\hline s54e & .541 & & \\
\hline s19e & .530 & & \\
\hline s24e & .510 & & \\
\hline s9e & .503 & & \\
\hline s26e & & 855 & \\
\hline s56e & & .845 & \\
\hline s16e & & .833 & \\
\hline sle & & .833 & \\
\hline s41e & & .824 & \\
\hline
\end{tabular}


INTERNATIONAL JOURNAL OF ACADEMIC RESEARCH IN BUSINESS AND SOCIAL SCIENCES

Vol. 9, No. 2, Feb, 2019, E-ISSN: $2222-6990$ @ 2019 HRMARS

\begin{tabular}{|c|c|}
\hline s51e & .814 \\
\hline s46e & .807 \\
\hline s31e & .798 \\
\hline s36e & .790 \\
\hline s6e & .776 \\
\hline s2e & .762 \\
\hline s27e & .719 \\
\hline s22e & .661 \\
\hline s11e & .650 \\
\hline s48e & .755 \\
\hline s43e & .734 \\
\hline s53e & 697 \\
\hline s42e & 697 \\
\hline s18e & .674 \\
\hline s38e & .663 \\
\hline s33e & .642 \\
\hline s52e & .633 \\
\hline s23e & .631 \\
\hline s47e & .601 \\
\hline s13e & .595 \\
\hline s17e & .593 \\
\hline s57e & .584 \\
\hline s58e & .579 \\
\hline s37e & .570 \\
\hline s8e & .540 \\
\hline $\mathrm{s} 28 \mathrm{e}$ & .520 \\
\hline s32e & .504 \\
\hline $\mathrm{s} 12 \mathrm{e}$ & .501 \\
\hline
\end{tabular}

Extraction Method: Principal Component Analysis.

Rotation Method: Varimax with Kaiser Normalization.

a. Rotation converged in 6 iterations.

\section{DISCUSSION}

Certain test instruments must be measured using several statistical methods to ensure a consistent and reliable test instrument. As supported by Baumgartner and Chung (2001), they stated that an instrument with construct validity is a valid and reliable instrument and could be used on any population that is being tested. Having formed 54 items out of 60 assessment instrument items on information management and lifelong learning skills that are valid and reliable, hence this study will be able to provide accurate information and feedback to the Faculty of Sports Science and Coaching to improve any shortcomings for better outcome in the future. 
INTERNATIONAL JOURNAL OF ACADEMIC RESEARCH IN BUSINESS AND SOCIAL SCIENCES

Vol. 9, No. 2, Feb, 2019, E-ISSN: 2222-6990 C 2019 HRMARS

\section{Conclusion}

The findings show that all the outlined features on information management and lifelong learning skills can be assessed based on the constructed instrument of this research questionnaire. All of the instrument items obtained high reliability value which is $r=.93$ and were validated using factor analysis statistics. A total of 54 questionnaire items were validated for attribute assessment on information management and lifelong learning skills. This research questionnaire instrument can be used by all UPSI lecturers at the Faculty of Sports Science and Coaching to evaluate the domain performance on student learning outcomes throughout the study semester.

\section{Acknowledgement}

This study was part of research funded by the Sultan Idris Education University (Code: GPU 20180057-107-01).

\section{REFERENCES}

Hashim, A. (2014). Panduan analisis data secara efisien. Bandar Baru Bangi: Dubook Press Sdn. Bhd.

Hashim, A. (2015). Pengujian, pengukuran dan penilaian Pendidikan Jasmani. Bandar Baru Bangi: Dubook Press Sdn. Bhd.

Ary, D., Jacobs, L. C., \& Razavieh, A. (2002) Introduction to research in education (6th ed). Belmont, CA: Wadsworth/Thomson Learning.

Baumgatner, T. A., \& H.Chung. (2001). Confidence limits for intraclass reliability coefficients. Measurement in Physical Education and Exercise Science 5: 179-188.

Cohen, J. (1992). A power primer. Psychological bulletin, 112(1), 155.

Gardner, H. (2006). Multiple Intelligences: New Horizons. London: Basic Books.

Ghani, M. F. A., \& Crow, G. M. (2017). amalan komuniti pembelajaran profesional: perspektif pemimpin sekolah cemerlang negara maju. JuKu: Jurnal Kurikulum \& Pengajaran Asia Pasifik, 1(3), 10-27.

Hamat, M. F., \& Nordin, M. K. N. C. (2012). Tinjauan kepentingan pembangunan modal insan di Malaysia (Review on the Importance of Human Capital Development in Malaysia). Jurnal AlTamaddun Bil, 7(1), 75-89.

Jalil, A., Azyani, N., \& Esa A. (2012). Kemahiran menyelesaikan masalah menerusi aktiviti kokurikulum (khidmat masyarakat) dalam kalangan pelajar. Universiti Tun Hussein Onn Malaysia.

Jalil, N. (2014). Kecenderungan pelajar cemerlang akademik terhadap pemilihan bidang PTV. (Doctoral dissertation, Universiti Tun Hussein Onn Malaysia). 
INTERNATIONAL JOURNAL OF ACADEMIC RESEARCH IN BUSINESS AND SOCIAL SCIENCES

Vol. 9, No. 2, Feb, 2019, E-ISSN: 2222-6990 C 2019 HRMARS

Kementerian Pengajian Tinggi (2015). Pelan Pembangunan Pendidikan Malaysia 2015-2025

(Pendidikan Tinggi). Putrajaya: Kementerian Pendidikan Malaysia.

Kementerian Pengajian Tinggi (2016). Panduan Pentaksiran Hasil Pembelajaran. Putrajaya:

Kementerian Pengajian Tinggi.

Maskan, N. (2013). Pelaksanaan pentaksiran berasaskan sekolah (PBS) bagi Mata Pelajaran Sains di Sekolah Kebangsaan Daerah Pontian, Johor (Doctoral dissertation, Universiti Tun Hussein Onn Malaysia). modal-insan-perlu-relevan\#ixzz2h0wRHI6J

Mohamad, H., \& Esa, A. (2013). Pembangunan modal insan holistik pelajar menerusi aktiviti kokurikulum. Universiti Tun Hussein Onn Malaysia.

Mohd Faizal Nizam Lee Abdullah \& Leow Tze Wei (2017). Kesahan dan kebolehpercayaan instrumen penilaian kendiri pembelajaran geometri tingkatan satu. Malaysian Journal of Learning and Instruction: Vol. 14, No. 1 (2017): 211-26.

Musa, W. A., \& Othman, R. (2014). Kesedaran Kendiri Terhadap Aktiviti Kokurikulum dan Keberkesanannya Kepada Remaja. Proceeding of the Social Sciences Research ICSSR, 9-10.

Pallant, J. (2005). SPSS survival manual (2nd edI). NewYork, NY: McGraw-Hill.

Prihamdani, D. (2016). Pengaruh komunikasi keluarga terhadap penguasaan Bahasa Inggris peserta didik kelas x di SMK Pgri 1 Tambun Kecamatan Tambun Selatan Kabupaten Bekasi. Jurnal Sekolah Dasar, 1(1).

Rinaldi, R., Hamzah, M. I., \& Nordin, N. M. (2015). Knowledge and attitude of lecturers toward usage of multimedia in teaching. Scientific Journal of PPI-UKM, 2(7), 300-302.

Tabachnick, B. G., \& Fidell, L. S. (2007). Using multivariate statistics (5th ed.). Bosrom: Pearson Educational, Inc.

Tuckman, B. W., \& Waheed, M. A. (1981). Evaluation an individualized science programme for community college students. Journal of Research in Science Teaching, 18, 489-495.

Yassin, M. (2013). Keseimbangan Modal Insan Perlu Relevan. Utusan Online. Retrived from: http://www.utusan.com.my/utusan/Dalam_Negeri/20130402/dn_02/Keseimbangan- 